\title{
Stress in Aquaculture Hatcheries: Source, Impact and Mitigation
}

\author{
Saima Rehman*, Adnan Hussain Gora, Irshad Ahmad and Sheikh Irfan Rasool \\ Madras Research Centre of Central Marine Fisheries Institute, \\ Chennai-600028, Tamil Nadu, India \\ *Corresponding author
}

\begin{tabular}{|c|c|}
\hline & A B S T R A C T \\
\hline Keywords & \multirow{5}{*}{$\begin{array}{l}\text { Stress is a major concern in aquaculture as many stressors are present in } \\
\text { hatchery which can predispose the fish to compromised growth and health } \\
\text { and ultimately promote disease. Larval stages may be more sensitive to } \\
\text { stress as compared with other stages, however little is known about } \\
\text { behavior and stress at this time. Fish which undergo metamorphosis are } \\
\text { most vulnerable to stress. Although with the increasing interest in fish } \\
\text { culture, the study of stress in the hatchery is an important field for future. } \\
\text { Proper management practices if followed in the hatchery will reduce the } \\
\text { stress and will ultimately lead to the better survival of fish. }\end{array}$} \\
\hline $\begin{array}{l}\text { Aquaculture, Stress, } \\
\text { Larval stage, Fish. }\end{array}$ & \\
\hline Article Info & \\
\hline $\begin{array}{l}\text { Accepted: } \\
26 \text { September } 2017\end{array}$ & \\
\hline $\begin{array}{l}\text { Available Online: } \\
10 \text { October } 2017\end{array}$ & \\
\hline
\end{tabular}

\section{Introduction}

Hatcheries are an important component of aquaculture system as they are designed and operated for cost-effective rearing of larvae. The expansion and sustainability of aquaculture depends on providing suitable conditions for the development of larvae. In hatcheries, the larval fish are reared in conditions which are at significant deviation from the natural environment. However, the environmental conditions of the culture system must comply with the physiological and behavioral needs of the fish larvae in order to achieve high survival and growth. Providing the larvae with the environment that best suits its growth and development without compromising the economics of the production system is a big challenge which the industry is facing all over the world.
The larval phase, which is spent in the hatchery, is the most critical phase of the entire production cycle after spawning This vulnerability of fish larvae is because of lack of a fully functional immune system (Bricknell and Dalmo, 2005); digestive system (Holt, 2011); osmotic system and compromised host microbe interaction (Vadstein et al., 2013). These factors, along with handling, induce stress in fish larvae resulting in high and sudden mortalities. Stress is an important factor, which should be considered in the successful rearing of larvae in hatcheries. Stress is defined as the nonspecific response of the organism to any demand made upon it (Selye, 1973). Although, the initial phase of stress, called as eustress, is beneficial to the organism, distress 
happens when certain factors cause physiological changes in an organism that ultimately compromise the organism's integrity (Selye 1984). Most of the research on stress is mainly focused on distress phase (Martinez Porchaset et al., 2009). The main aim in the hatchery is to produce a reliable and sufficient good quality of fish seed but certain stressors affect the whole process of production resulting in high mortality rates, and economic loss in aquaculture sector. The intensive culture of larvae exposes them to considerable stressors of chemical, physical and biological nature and in addition, some of these stressors can occur in an intermittent manner or as pulses, which may further amplify their negative effects. Therefore, the recognition of theses stress sources, and their mitigation are critical in the successful operation of hatchery.

\section{Sources of stress in hatchery}

Most common stressors, which are present in hatchery, include poor water quality (Tomasso et al., 1981a, 1981b), xenobiotic toxic molecules (Schlenk et al., 1999; Griffin et al., 1999), and handling (Davis et al., 1993). These stressors can be of a short-term acute nature, like handling or may be longterm chronic type, like an extended period of poor water quality. Since the transport, feeding and treatment are routine activities of a hatchery operation, the larvae are more exposed to both chronic and acute stressors. A similar risk for poor water quality also exists in the hatcheries because of the high stocking densities, which are common in intensive culture (Kenneth, 2006).

Water quality is an important factor in the production results of any hatchery and is the foundation of healthy fish-pathogenenvironment relationship. Water quality requirements of the larvae are species specific. Generally, larvae or fry of any species have stringent water quality requirements than their larger con-specifics. Any change in the water quality constituents can greatly alter the normal physiology of larvae causing acute and chronic stress.

\section{Water temperature}

Water temperature regulates major physiological processes of fish larvae and a two to three-order magnitude change in temperature will have a profound affect on physiological mechanisms (Blaxter, 1992). Temperature affects the time of hatching, development of larvae, cellular function, muscle ontogeny and development and ontogeny of internal organs (Herzig and Winkler 1986). Besides this, external morphology, meristic characters (TorresNúñez et al., 2014), appearance of skeletal deformities, sex determination, delayed feeding (Dou et al., 2005), changes in the rates of enzymatic reactions, swimming performance, growth (overall survival and lifespan of fish are affected by temperature (Meeuwig et al., 2013).

\section{pH of water}

The $\mathrm{pH}$ is an important variable in water quality as many reactions are $\mathrm{pH}$ dependent and normal waters contain both acids and bases. The biological processes in water tend to increase either acidity or basicity and the interactions among these opposing acidic and basic substances determine $\mathrm{pH}$. Carbon dioxide concentration, which is acidic, plays an important role in regulating $\mathrm{pH}$. The alkalinity of water results primarily from bicarbonate and carbonate ions derived from the reaction of carbon dioxide in water tends to buffer water against excessive $\mathrm{pH}$ change (Boyd, 2011). Fish larvae are highly sensitive to $\mathrm{pH}$ changes than juveniles and adults and at this stage significant effects are most likely to be detected. This can partly be understood 
due to insufficient acid-base regulation prior to the formation of gills (Falk-Petersen, 2015). Studies have shown many impacts of predicted $\mathrm{CO} 2$ concentrations on larval fish on sensory abilities like olfaction (Munday et al., 2009), behaviour (Dixson et al., 2012), otoliths (Checkley et al., 2009; Bignami et al., 2013) development, tissue and organ structure (Frommel et al., 2012; 2014), survival of eggs specifically the hatching success (Chambers et al., 2013), and survival of very early larval stages (Bromhead et al., 2015). However, other studies were not able to find an effect on survival (Munday et al., 2009). Low-pH seawater slow down the embryonic and early larval development causing appreciable larval mortality (Miller et al., 2016)

\section{Photoperiod}

Light plays an important role as a biological regulator controlling feeding, digestion, and reproduction in fish. Light influences the basic signalling systems by affecting the light sensitive brain tissues including the retina of the eye containing serotonin, an important neurotransmitter. Light comprises different components such as quantity (light intensity), quality (spectral composition), light distribution (point source or evenly), and cycling (photoperiod and season).

The outdoor light conditions are quite defined depending on latitude, season, depth, and algal blooms. However, hatchery conditions often provide very different conditions from natural systems like light intensity is lower, spectral composition is different with e.g. lack of UV radiation, and 24-hour light is commonly used. This may remove any diurnal signals from the fish larvae, with unknown impacts on larval development. Unfavourable light conditions which do not facilitate good feeding behaviour induces stress conditions since most marine fish larvae are visual feeders (Tamazouzt, 2000)
Besides the physicochemical aspects of water, several routine practices in the hatchery like overcrowding, handling and transport can cause stress in fish (Wedemeyer, 1996a). High stocking density produces a wide variety of effects on fish such as alterations in behavior (Alanara and Brannas 1996), poor feed utilization(Jorgensen et al., 1993), behavioural (Schreck et al., 1997) and hormonal changes (Leather and Cho, 1985) resulting in poor growth (Bjornsson, 1994) and survival(Sodeberg and Meade 1987). High stocking density also causes immunosuppression (Tort et al., 1996) and induces mobilization of energy sources (Vijayan et al., 1988, 1990). Capture and handling elicite rapid, marked elevations of plasma cortisol and glucose level in the fish (Barton et al., 1993). Transportation causes a physiological stress response by accumulation of carbon dioxide and ammonia in fish hauling tanks, increasing concentrations of circulating cortisol level and reducing survival rate (Schreck et al., 1989).

Behavioral interactions occur between fish in a hatchery. Agonistic encounters, interspecific competition, social hierarchies, and territoriality dominance is a significant source of social stress in fish indicated by manifold changes in physiological and neuroendocrine processes (Summers, 2002; Blanchard, 1991). Fishes show aggressive behaviors and predation causing unnecessary stress and physical injury. Fin nipping, scale loss from ramming, reduced growth, pathological changes in gastrointestinal tissue, and increased susceptibility to diseases can occur in defeated individuals (Earley et al., 2004).

\section{Stress response}

Stress response involves all three regulatory systems, neural, endocrine and immune and is common in all the vertebrates including fish. Perception of stress by the sensors of the 
nervous system causes the immediate secretion of corticosteroid releasing hormone (CRH) by the preoptic nucleus of the hypothalamus. The stimulated $\mathrm{CRH}$ receptors of the pituitary gland induce the release of adrenocorticotropic hormone (ACTH) into the circulation that subsequently stimulates release of cortisol by the interrenal cells (Pickering, 1981). The other axis that is related to stress is the sympatheticochromaffin axis. The sympathetic nerve fibers innervate the chromaffin cells and stimulate the release of cateholamines via cholinergic receptors (Reid et al., 1996; Catecholamines, release is rapid and the circulating levels of these hormones increase immediately with stress (Randall and Perry, 1992).

Stress response promotes the survival and recovery of individuals during and after challenging events (Greenberg et al., 2002).However, this response is characterized by release of glucocorticoid hormones (Axelrod and Reisine 1984), resulting in secondary system-level and tertiary wholeanimal changes. These changes include increase in carbohydrate catabolism (Barton 2002), mobilization of energy reserves (Wendelaar Bonga, 1997), increases in aerobic and anaerobic metabolism(De Boeck et al., 2001), increase in standard metabolic rate (Lankford et al., 2005) and reduction in feeding (Lankford et al., 2005). Chronic elevation of circulating cortisol concentrations also reduces growth despite normal feeding behaviour (Bernier et al., 2004) showing that there is a metabolic cost of stress. Variable changes in plasma levels of Growth hormone $(\mathrm{GH})$ occur as a result of stress. GH is released from pituitary and stimulates the release of insulin-like growth factor (IGF-1) which in turn affects cell growth and differention. Thyroid hormones throxine $\left(\mathrm{T}_{3}\right)$ and its peripheral metabolite triiodothyronine $\left(\mathrm{T}_{4}\right)$ is also required for normal growth (Leatherland, 1994).
Starvation causes an increase in plasma $\mathrm{GH}$ levels (Fabridge and Leatherland, 1992). Growth inhibiting effects can occur due to stress through depression of $\mathrm{T}_{3} \& \mathrm{~T} 4$, either directly or indirectly from a stress- reduced reduction in food intake. (Pickering, 1991).Stress effects mediated by cortisol treatment suppress $\mathrm{T}_{3}$ and $\mathrm{T}_{4}$ levels (Vijayan and Leatherland, 1989), depress somatic growth and often associated with hyperglycemia (Lidman et al., 1979).

\section{Stress and immune system}

The specific and non-specific immune system in fish can be compromised in fish due to stress factors present in the hatchery leading to establishment of infection. Different kind of stressors induces a variety of immune changes and the outcome of a stress response will depend on the intensity of the stressor and its duration. (Wendelaar Bonga, 1997) Stress response, therefore, can either activate or suppress immune function (Dhabhar et al., 2008). Majority of stressors, however, produces deleterious effects. During the activation phase, enhanced innate humoral immunity such as increased levels of lysozyme and C3 proteins can occur after acute stress (Demers and Bayne, 1997). Stressful hatchery conditions like crowding (Vazzana et al., 2002), variable water temperature (Varsamos et al., 2006), environmental contaminants, oxidative stress (Franco et al., 2009) and deficient diet (Montero et al., 1999)which cause chronic stress normally show suppressive effect.

Most of these effects are reduced immunocompetence, increased level of cortisol, decreased level of lysozyme. Stress reduces the number of circulating Blymphocytes, decreases the antibody response, complement hemolytic activity, $\operatorname{IgM}$ and induce apoptosis (Franco et al., 2009). 


\section{Stress related Diseases}

Fish and microorganisms present in the rearing environment are most often harmless or beneficial. However, this fishmicroorganism interaction when influenced by stress factors result in infections and epizootic disease (plumb 1994). Fish pathogens are generally classified as obligate or facultative pathogens and the stressmediated fish diseases are mostly caused by facultative bacterial pathogens (plumb, 1994), external fungi, (Pickering and Willoughby., 1982), protozoan parasites (Alavarez et al., 1993). Some of the common bacterial diseases occurring in hatcheries can be stressmediated such as vibiosis (vibrio species) and motile Aeromonas septicaemia (Aeromonashydrophila), Enteric red mouth(Yersinia ruckeri), Enteric septicemia (Wedemeyer et al., 1984., Pickering et al., 1991) Furunculosis (A. salmonicida) is often correlated with stressful water quality conditions and fish culture procedures (Nomura et al., 1992.,). Bacterial gill disease (Flavobacterium branchiophilum) occurs in hatchery mostly with management errors such as overfeeding, overcrowding, inadequate water flow rates, low DO levels, increased unionized ammonia and accumulation of suspended particulate matter that causes gill irritation. (Klonz, 1993). Behavioural conflicts and in presence of pathogen can result in MAS in defeated individuals (Peters et al., 1988). Ichthyophthirius, Gyrdoactylus and Lernae are particularly some of the parasites having a relationship between temperature and infection (Plumb, 1994). Stress and cortisol treatment has been shown to increase susceptibility to parasitic infections (Saeij et al., 2003a). A number of noninfectious diseases such as skeletal abnormalities, swim bladder stress syndrome and coagulated yolk disease occur due to improper management of rearing conditions (Soares et al., 1994).

\section{Stress and Reproductive inhibition}

In the hatchery, brooders may be in-house or may come from the wild conditions. Wild brooders are the main stay of most of the marine hatcheries. When the wild fish are brought into the hatchery, it generates stress that will inhibit their sexual maturation for a certain time (latency period) (Pickering et al., 1987). Effect of number of stressors like low pH (Freeman, 1983), contaminants and industrial effluents on reproduction has been documented. Stress associated with capture or confinement of wild brooders and handling for the collection of gametes (Mellotti et al., 1992) influences reproduction by affecting circulatory levels or changing seasonal pattern of reproductive hormones. Effect of stress is mediated mainly through HPI axis resulting in increase in plasma cortisol level and catecholamines. Increased plasma cortisol has shown suppressive effects on plasma sex hormones like testosterone, oestradiol and gonadotropin, pitutitary level of gonadotropin, circulating vitellogenin and ovary weight in vitro (Carragher and Sumpter, 1990). Repeated acute stress prior to spawning results in delayed ovulation, reduced egg size in females and lowered sperm counts in males (Pankhurst and Carragher, 1992). Progeny from the stressed fish is also known to have a lower survival rate as compared to unstressed fish (Short $e t$ al., 1995).

\section{Reduced feeding behavior and growth}

Stress caused by handling such as transferring brooders from one tank to another tank and size grading to avoid competition results in loss of feeding behavior for various period of time depending on the severity of stress and physiological state of fish. Stress disrupts feeding behavior like appetite, visual and chemosensory ability, restricted area searching, responding to and capturing prey 
and handling and ingestion of prey (Beitinger, 1990). Low $\mathrm{pH}$ of water has shown to depress attraction to food scent (Jones et al., 1987). Natural mortality in fish occurs mostly during larval stages, due to predation and starvation (Hunter, 1981). Starvation of larvae in hatcheries can occur due to poor acceptance and inadequate quality of food leading to huge mortality(Ola and Davis,1992).Starvation in larvae can also cause behavioural abnormalities such as depression and cessation of positive phototaxis, abnormalities in gas bladder development leading to lack of buoyancy control and early death (Fletcher, 1997).

\section{Stress and behvioural response}

Fish respond to stressors by change in their behavior like swimming performance, thermoregulation, orientation, avoidance, chemoreception, feeding, predator evasion, and learning (Schreck et al., 1997) In many cases, these changes are adaptive and therefore, increase the probability of survival(Olla., 1996) and are also sensitive indicator of physiological and biochemical changes occurring in response to stress (Marcucella \& Abramson,1978). Pathogenic microorganisms and parasitic infestation can cause behavioral changes in fish (Post, 1987) which may include increased activity, flashing at the surface and ultimately decreased activity and lethargy (Thoesen, 1994). Leaping and rolling at the surface can occur as a result of parasitic infestations (Furevik et al., 1993).

Changes in temperature preferences (Reynolds et al., 1978) and infection with pathogens (Tsai and Hoh, 1995) has also been documented. Stress can interfere with learning responses (Schreck et al., 1997), however there is little information that directly relates the effect of stress on learning ability or memory of fish.

\section{Indicators of stress in fish}

Measuring stress in fish is to determine how the health, performance, and welfare of fishes are being influenced by different stressors like handling, rearing, and transport (Portz et al., 2006), as well as anesthesia (Trushenski et al., 2012) affecting captive broodstock health, survival of larvae and production efficiency. The main aim of assessing is to reduce it and maximize growth and survival. Quantification of stress basically refers to quantification of primary, secondary, and tertiary responses following HPI axis activation like gene expression, immune function, metabolism, growth, reproduction, performance, behavior. Measurement of pre- and poststressor levels of the indicator are required for quantification, however, mostly the latter response is measured once following stressor exposure (Iwama et al., 2007; Schreck, 2010). Physiological indicators of stress include all the responses between the cellular and molecular level and the whole-animal level.

\section{Cellular and molecular indicators}

Oxidative stress, by-product of metabolism, occurs when ROS production overwhelms the counter balancing capacities of antioxidants damaging biological molecules like lipids, proteins, RNA, and DNA (Costantini, 2008,). Oxidative stress is quantified by multiple markers through a variety of colorimetric assays measuring ROS, antioxidant levels; or measuring damage to biomolecules (Lesser, 2006) in plasma, serum, urine, tissue homogenates, or cell cultures (Valavandis et al., 2006). Heat shock proteins (HSP) sensitive to a range of stressors like rapid temperature and salinity challenges, and handling can be a reliable indicator of stress (Donaldson et al., 2008). HSP's are basically molecular chaperones having role in folding, repairing, and catabolizing protein (Moseley, 1997). HSPs controlled by Heat Shock Factor 
1 (HSF1) induces cellular stress response and expression increases to maintain cellular homeostasis (Iwama et al., 2004). In fish, a number of genes like cytochrome c. transcription factor JUNB, NUPR1 have been investigated as potential biomarkers for various stressors (Jefferies et al., 2012). Changes in the gene expression related to inflammation, protein degradation, immune response onset of recovery poststress related to gluconeogenesis, glycogenolysis, and energy metabolism in the liver have been observed (Wiseman et al., 2007).

\section{Primary and secondary physiological indicators}

Primary and secondary stress indicators are very useful in assessing responses related to specific aquaculture or handling practices, or acute disturbances in the field. Cortisol and catecholamines are commonly measured as stress indicator (Barton, 2002). Cortisol responds more slowly than catecholamines to specific stressors, it can be quantified in laboratory or field settings although the later provides very accurate information about the response to acute stressors. (Romero and Reed, 2005) Poststress glucocorticoid levels can provide information about specific stimuli (e.g., capture and handling stress, different holding conditions, acute exposures. Secondary stress indicators commonly measured include glucose elevation (Barton, 2002); lactate elevation, osmolality or specific ions, leukocytes (Davis et al., 2008).

\section{Whole-organism indicators}

A number of aspects of fish performance such as changes in growth, disease resistance, metabolism, cardiac activity, swimming performance, behavior, fitness, and even survival are measured in whole-organism (or tertiary) responses to stressors (Sadoul and Vijayan, 2016).

\section{Mitigation of stress factors}

\section{Proper capturing and handling of brooders}

Handling and grading are highly stressful and more complicated because of the aquatic medium. Handling requires a foreign element into the water to catch the fish and if not done correctly, excessive stress can jeopardize fish, disrupts the protective mucous coating and fish scales and increases susceptibility to parasitic or pathogenic infection (Post, 1987). To avoid disrupting the mucous coat of fish and losses of scales, use of wet hands or soft cotton gloves while handling fish is always recommended. Stress should always be minimized while capturing and handling brooders and this can be partly achieved by selecting suitable gear during the operation. The appropriate makeup of netting varies with species, and depending on presence or absence of scales and scale type. Knotted mesh can dislodge fish scales resulting in parasitic and pathogenic invasion The best fishing gear for catching the wild fish is the fish barrier which is a fixed trap placed at the outlet of coastal lagoons. When fish enters the trap following their migratory instinct, they can be captured without much stress. The seine net that is used in ponds and tanks can also give good results but should be handled very carefully, while harvesting only a small number of fish per haul. To avoid, the use of knotless stretched mesh nylon nets, as well. Healthy adult fish can also be captured by hook and line, but care should be taken to reject all fish with major injuries in their mouth, gut or, even worse, gills, as well as those which have lost too many scales when hauled on board (Tucker, 1985; Tucker and Robinson, 1990). Temperature effect the stress response to handling and capturing, as water hold less less oxygen at higher temperatures (Wheaton, 1977; Lawson, 1995). Most of these activities should be performed during the cooler portions of the 
day or initiated at night so as to finish in the early morning. Temperature-related stress can occur any time when fish are handled, but fish are most vulnerable during high temperature resulting in mortality in both the short and long-term (Piper et al., 1982).

\section{Proper transportation}

Much of the research has been focused on overcoming the challenges of harvesting and transporting fish due to wide inter-specific variations in physiological responses to these stressors (Barton, 2002). Level of plasma cortisol in different species can vary by as much as two orders of magnitude due to identical stressors. Some fishes can be transported easily other than maintaining proper water quality and temperature, however, others species require specific additional precautionary steps so as to prevent ionic and osmotic imbalances resulting in mortality (Carmichael and Tomasso, 1988).

Repeated handling and transport should be avoided and there should be a recovery period. Physiological responses of fish after acute netting, handling and transport can recover after a period of $6 \mathrm{~h}$ to 1 day, however, it may also vary from 10 days to 2 weeks if they are persisting, but not lethal (Schreck et al., 1997).

Transporting a fish is a multiple-phase operation and should be designed in such a way to minimize stress (Piper et al., 1982).The temporary holding and transport containers should be selected carefully to reduce additional and potentially fatal stress to recently caught fish. They should be heat insulated and filled with water from the same location where the fish have been caught. The containers should be round in shape or square with rounded corners so as to avoid skin abrasions and mechanical shocks and large enough to allow the fish a fair degree of movement. A correct choice of fish loading density (fish weight per unit volume of water) is of paramount importance in minimizing the stress. The fish density should be inversely proportional to transport time and water temperature. Fish should not be fed for about $24 \mathrm{~h}$ prior to harvest and transport to avoid feces and fouling of the transport water. In the container oxygen saturation should be around $100 \%$ and the animals should be brought to the hatchery as soon as possible: speed and care are always recommended. A variety of water additives (anesthetics, hypnotic drugs, mineral salts, polymers), fasting, hypothermia, and reduced light intensity have been developed to reduce the physiological effects of transportation on fish health (Wedmeyer, 1997)

\section{Maintaining water quality requirements}

To achieve optimal growth and survival of newly hatched larvae, it is important to have good water quality in the hatchery. The quality of water should be more or less stable without any fluctuation. The hatchery should have both heating and cooling plant to control the temperature fluctuations because natural water may have a sub-optimal temperature for growth and survival for the different life stages (Lekang, 2007).

Larvae are sensitive to high gas saturation in the water and as a result can become diseased quickly and thus aerators should be used properly to avoid such problems in hatchery. Gas bubble disease can occur if the nitrogen gas concentration in the water is above 101$102 \%$ (Gunnarsli et al., 2008; Noga, 2010). $\mathrm{CO}_{2}$ super-saturation is not common because, its solubility is higher than that of oxygen and nitrogen but the tolerance of aquatic organisms for $\mathrm{CO}_{2}$ in the water is, however, limited (Good et al., 2010). The Ph of water also plays a significant role in the hatchery and thus ph should be measured regularly and 
adjustment should be done to avoid large fluctuations.

\section{Control of microorganism}

In the hatchery, diseases can be controlled by the disinfection of the inlet water. The most common system is ultraviolet (UV), ozone. UV lamp can be used to send out UV radiation having a sufficient dosage to inactivate microorganism. Ozone gas (O3), a very strong oxidizing agent produced by ozone generator can also be used in the hatchery for disinfection of water. Ozone can also reduce water turbidity, watercolor, organic carbon, metal ions and algae (Summer felt, 2003; Masters et al., 2008)

\section{Stabilization of water}

Disinfection of water reduces large amount of microorganisms but still the water will have dead, inactivated bacteria and decomposed organic matter which can be a good food source for the remaining bacteria. Microbial stabilization or maturation is a method where the disinfected water is allowed to pass through a filter where biological organisms growing naturally can stabilize the water quality by inhibiting growth of bacteria. There should also be a retention time for general stabilization of water quality before it is passed into hatchery (Olafsen, 2001; Brunvold, 2010)

\section{Use of immunotimulants}

The immunomodulation of larval fish is a potential method for improving larval survival by increasing the innate defence of the developing animals until its adaptive immune response is sufficiently developed to mount an effective response to the pathogen.

The immunostimulants, as dietary supplements can be used during periods of high stress, such as grading, reproduction, sea transfer and vaccination (Bricknell and Dalmo, 2005).

\section{References}

Adams, S. M. M. (ed.) 1990. Biological indicators of stress in fish. American Fisheries Society Symposium Series 8, Bethesda, Maryland.

Alanärä, A. and Brännäs, E. 1996. Dominance-feeding behaviour in Artic charr and rainbow trout: the effect of stocking density., J.Fish Biol 48: 242254.

Alvarez-Pellitero, P. and Sitja-Bobadilla, A. 1993. Ceratomyxa spp. (Protozoa: Myxosporea) infections in wild and cultured sea bass, Dicentrarchus labrax, from the Spanish Mediterranean area. J.Fish Biol 42, 889-901

Axelrod, J., and Reisine, T.D. 1984. Stress hormones: Their interaction and regulation. Science, 224(4648): 452459.

Barton, B. A.,2002. Stress in fishes: a diversity of responses with particular reference to changes in circulating corticosteroids. Integr. Comp. Biol. 42, 517-525.

Barton, B. A., C. B. Schreck, and L. D. Barton. 1987. Effects of chronic cortisol administration and daily acute stress on growth, physiological conditions, and stress responses in juvenile rainbow trout. Dis. Aquat. Org, 2173-185.

Beitinger, T. L., 1990. Behavioral Reactions for the Assessment of stress in Fishes. J Great Lakes Res.. Internal. Assoc, Great Lakes Res., 16(4): 495-528.

Bernier NJ, Bedard N, Peter RE.,2004 Effects of cortisol on food intake, growth, and forebrain neuropeptide $\mathrm{Y}$ and corticotropin-releasing factor gene expression in goldfish. Gen. Comp. Endocrinol. 135: 230-240. 
Bignami S, Enochs IC, Manzello DP, Sponaugle S, Cowen RK. Ocean acidification alters the otoliths of a pantropical fish species with implications for sensory function. Proc Natl Acad Sci USA. 2013; 110 (18):7366-70.

Björnsson, B. 1994. Effects of stocking density on growth rate of halibut (Hippoglossus hippoglossus L.) reared in large circular tanks for three years. Aquaculture 123: 259-270.

Blanchard,R., McKittrick,C., Blanchard,D.,2001.Animal models of social stress: effects on behavior and brain neurochemical systems. Physiol Behav, 73: 261-271.

Boyd CE, Tucker CS, Viriyatum R., 2011. Interpretation of $\mathrm{pH}$, acidity and alkalinity in aquaculture and fisheries. $N$ Am J Aquac 73:403-408.

Boyd CE, Walley WW., 1975. Total alkalinity and hardness of surface waters in Alabama and Mississippi. Bulletin 465, Alabama Agricultural Experiment Station, Auburn University, Auburn

Bricknell I, Dalmo RA., 2005. The use of immunostimulants in fish larval aquaculture. Fish Shellfish Immunol 19: 457-472.

Bromhead D, Scholey V, Nicol S, Margulies D, Wexler J, Stein M, et al., 2015.The potential impact of ocean acidification upon eggs and larvae of yellow fin tuna (Thunnus albacares). Deep Sea Res Part II. Mar; 113:268-79.

Brunvold, I., 2010. Microbial ecology in the early life stages of intensively rearedmarine species, $\mathrm{PhD}$ Thesis, University of Bergen.

Busch, R.L., 1990. Channel catfish culture in ponds. In: Tucker, C.S., Robinson, E.H. (Eds.), Channel Catfish Farming Handbook. Van Nostrand Reinhold, New York, USA, pp. 19-84.
Carmichael, G.J., Tomasso, J.R., 1988. Survey of fish transportation equipment and techniques. Progr. Fish-Cult.50: 155-159.

Carragher, J. F., and J. P. Sumpter. 1990. The effect of cortisol on the secretion of sex steroids from cultured ovarian follicles of rainbow Gen.Comp. Endocrinol, 77: $403-407$.

Chambers RC, Candelmo AC, Habeck EA, Poach ME, Wieczorek D, Cooper KR, et al., 2013. Ocean acidification effects in the early life-stages of summer flounder, Paralichthys dentatus. Biogeosciences Discuss., 10:13897929.

Checkley DM, Dickson AG, Takahashi M, Radich JA, Eisenkolb N, Asch R. Elevated $\mathrm{CO}$ enhances otolith growth in young fish. Science. 2009 Jun 26; 324:1683.

Costantini, D.,2008. Oxidative stress in ecology and evolution: lessons from avian studies. Ecol. Lett. 11: 12381251.

Davis, A. K., Maney, D. L. and Maerz, J. C.,2008. The use of leukocyte profiles to measure stress in vertebrates: a review for ecologists. Funct. Ecol. 22: 760-772.

Davis, L.E. \& Schreck,C.B.,1997. The engertic response to handling stress in juvenile coho salmon. Transactions of the American Fisheries Society, in press

Davis,K.B.,J.Newsom,andB.A.Simco.1993.P hysiological stress in channel catfish harvested by lift net, vacuum pump, or turbine pump. Journal of Applied Aquaculture 3:297-309

De Boeck, G., Alsop, D., and Wood, C. 2001. Cortisol effects on aerobic and anaerobic metabolism, nitrogen excretion, and wholebody composition in juvenile rainbow trout. Physiol. Biochem. Zool. 74(6): 858-868.

Demers, N.E., Bayne, C.J., 1997. The 
immediate effects of stress on hormones and plasma lysozyme in rainbow trout. Dev. Comp. Immunol. 21 (4): 363-373.

Dhabhar, F.S., 2008. Enhancing versus suppressive effects of stress on immune function: implications for immunoprotection versus immunopathology. Allergy Asthma Clin. Immunol. 4 (1): 2-11.

Dixson DL, Pratchett MS, Munday PL. 2012. Reef fishes innately distinguish predators based on olfactory cues associated with recent prey items rather than individual species. Anim Behav., 84(1):45-51.

Dou, S. Z., Masuda, R., Tanaka, M. and Tsukamoto, K. (2005), Effects of temperature and delayed initial feeding on the survival and growth of Japanese flounder larvae. Journal of Fish Biology, 66: 362-377.

Earley, R.L.. Blumer, L.S., Grober M.S 2004. The gall of subordination: changes in gall bladder function associated with social stress Proc R Soc Lond B Biol Sci, 271., 7-13

Fabridge KJ, Leatherland JF (1992) Plasma growth hormone levels in fed and fasted rainbow trout (Oncorhynchus mykiss) are decreased following handling stress. Fish Physiol Biochem 10: 67-73.

Falk-Petersen IB., 2015. Comparative organ differentiation during early life stages of marine fish. Fish Shellfish Immun., 19:397-412.

Fenner, R.M (2001) The Conscientious Marine Aquarist T.F.H. Publications, Neptune City, NJ

Ferreira, M., Moradas-Ferreira, P., ReisHenriques, M. A., 2005: Oxidative stress biomarkers in two resident species, mullet (Mugil cephalus) and flounder (Platichthys flesus), from a polluted site in River Douro Estuary, Portugal. Aquatic Toxicology., 71, 3948.
Fletcher TC. In: Dietary effects on stress and health In: Fish Stress and Health in Aquaculture. Iwama GK, Pickering AD, Sumpter JP, Schreck CB, editors. Cambridge Univ. Press; Cambridge, UK: 1997. pp. 223-246.

Franco, R., Sanchez-Olea, R., Reyes-Reyes, E.M., Panayiotidis, M.I., 2009 Environmental toxicity, oxidative stress and apoptosis: menage a trois. Mutat Res. 674(1-2), 3-22.

Frommel AY, Maneja R, Lowe D, Malzahn AM, Geffen AJ, Folkvord A, et al., Severe tissue damage in Atlantic cod larvae under increasing ocean acidification. Nat Clim Chang. 2012; 2(1):42-6

Frommel AY, Maneja R, Lowe D, Pascoe CK, Geffen AJ, Folkvord A, et al., Organ damage in Atlantic herring larvae as a result of ocean acidification. Ecol Appl. 2014; 24(5):1131-43

Fuchs, E., Flügge G., (2002) Social stress in tree shrews: effects on physiology, brain function, and behavior of subordinate individuals Pharmacol Biochem Behav, 73, pp. 247-258.

Furevik, D.M., Bjordal, A., Huse, I. and Fernoe, A. (1993). Surface activity of Atlantic salmon (Salmo salar L.) in net pens. Aquaculture, 110, 119-28.

Good, C., Davidson, J., et al., (2010) 'The effects of carbon dioxide on performance and histopathology of rainbow trout Oncorhynchus mykiss in water recirculation aquaculture systems.' Aquacultural Engineering 42(2): 51-56.

Greenberg, N., Carr, J.A., and Summers, C.H. 2002. Causes and consequences of stress. Integr. Comp. Biol. 42(3): 508516.

Griffin, R. J., Cocker, D. R., III; Flagan, R. C., Seinfeld, J. H. 1999. Organic aerosol formation from oxidation of biogenic hydrocarbons J. Geophys. Res., 104, 
D3 3555- 3567.

Gunnarsli, K.S., Toften, H. et al., (2008) 'Effects of nitrogen gas supersaturation on growth and survival in juvenile Atlantic cod (Gadus morhua L.).' Aquaculture 283(1-4): 175-179.

Hartl, F. U., 1996: Molecular chaperones in protein folding. Nature381, 571-580.

Herzig, A., and H. Winkler. "The influence of temperature on the embryonic development of three cyprinid fishes, Abramis brama, Chalcalburnus chalcoides mento and Vimba vimba." Journal of Fish Biology 28.2 (1986): 171-181.

Holt G. J.,2011. Larval Fish Nutrition. John Wiley and Sons, Chichester, UK.

Hunter,J.R.1981. Feeding ecology and Predation of marine fish larvae. In Marine fish Larvae :Morpholgy, Ecology, and Relation to Fisheries. Lasker, R.(ed.) pp.33-77. Washinton Sea Grant Program, University of Washinton, Seattle. Distributed by University of Washinton Press.

Iwama, G. K.,2007. The welfare of fish. Dis. Aquat. Organ. 75, 155-158.

Iwama, G. K., Afonso, L. O. B., Todgham, A., Ackerman, P. and Nakano, K.,2004. Are hsps suitable for indicating stressed states in fish? J. Exp. Biol. 207, 15-19.

Jeffries, K. M., Hinch, S. G., Sierocinski, T., Clark, T. D., Eliason, E. J., Donaldson, M. R., et al., (2012). Consequences of high temperatures and premature mortality on the transcriptome and blood physiology of wild adult sockeye salmon (Oncorhynchus nerka). Ecol. Evol. 2, 1747-1764.

Jones, K.A., Brown, S.B. and Hara, T.J.1987. Behavioral and biochemical studies of onset and recovery from acid stress in Arctic char, Salvelinus alpines. Canadian journal of Fisheries and Aquatic Sciences,44, 373-81.

Jorgensen, E.H., Christiansen, J.S. and
Jobling, M. 1993. Effects of stocking density on food intake, growth performance and oxygen consumption in Artic charr (Salvelinus alpinus). Aquaculture, 110: 191-204.

Kenneth B. Davis Management of Physiological Stress in Finfish Aquaculture North American Journal of Aquaculture 68:116-121, 2006.

Kinghorn, B. 1983. Genetic variation in food conversion efficiency and growth in rainbow trout. Aquaculture, 32, 141-55.

Lahnsteiner F., 2012. Thermotolerance of brown trout, Salmo trutta, gametes and embryos to increased water temperatures. J. Appl. Ichthyol.,28: $745-751$.

Langston, A. L., Hoare, R., Stefansson, M., Fitzgerald, R., Wergeland, H., Mulcahy, M., 2002: The effect on non-specific defence parameters of three starins of juvenile Atlantic halibut (Hippoglossus hippoglossus L.). Fish Fish Shellfish Immunol, 12 : 61-76.

Lankford, S.E., Adams, T.E., Miller, R.A., and Cech, J.J., Jr.. 2005. The cost of chronic stress: Impacts of a nonhabituating stress response on metabolic variables and swimming performance in sturgeon. Physiol. Biochem. Zool. 78(4): 599-609.

Lawson, T.B., 1995. Fundamentals of Aquaculture Engineering. Chapman \& Hall, New York, p. 355.

Leatherland, J.F. and Cho, C.Y.,1985. Effect of rearing density on thyroid and interrenal gland activity and plasma and hepatic metabolite levels in rainbow trout, Salmo gairdneri Richardson. J. Fish Biol. 27: 583-592.

Leatherland, J.F.,1994. Reflections on the thyroidology of fishes: from molecules to humankind. Guelph Ichthyol Rev. 2: $1-67$

Lesser, M. P., 2006: Oxidative Stress in Marine Environments. Biochemestry 
and Physiological Ecology., 68 253278.

Lidman, U., Dave, G., Johanson-Sjobeck, M.L., Larsson, A. and Lewander, K.,1979. Metabolic effects of cortisol in the European eel, Anguilla anguilla (L.). Comapartive Biochemistry and physiology, 63A, 339-44

Maneja, R.H., Frommel, A.Y, Geffen, A.J., Folkvord, A., Piatkowski, U., Chang M., 2013. Effects of ocean acidification on the calcification of otoliths of larval Atlantic cod Gadus morhua. Mar Ecol Prog Ser., 477:251-8.

Marcucella, H., Abramson, C.I.,1978. Behavioral toxicology and teleost fish. In Behavior of fish and Other Aquatic animals. Mostofsky, D.I.(ed.) pp33-37. Academic press, New York.

María, D. A, María. L, Rosa, C., 2015. Body and Muscle Growth of Pre-Larvae and Larvae of Turbot, Scophthalmus Maximus., Reared at Three Different Temperatures, Open Journal of Animal Sciences, , 05, 04, 402.

Martinez-Porchas, M., L.R. MartinezCordova and R. Ramos-Enriquez. 2009. Cortisol and Glucose: Reliable indicators of fi sh stress? PanAmerican.Journal of Aquatic Sciences. 4(2): 158-178.

Masters, A.L., Vinci, B.J., et al., (2008) 'Performance characterization of infl uent and effl uent treatment systems: A case study at Craig Brook National Fish Hatchery.'Aquacultural Engineering 38(1): 66-76.

McBride, J.R., Fagerlund, U.H.M., Dye, H.M., Bagshaw, J., 1986. Changes in structure of tissues and in plasma cortisol during the spawning migration of pick salmon, Oncorhynchus gorbuscha (Walbaum). J. Fish Biol. 29, 153-166.

Meeuwig I, Bayer J, Seelye J., 2013. Effects of temperature on survival and development of early life stage Pacific and Western brook Lampreys. T. Am. Fish. Soc., 134: 119-27.

Mehranvar, L., Healey, M., Farrell, A., Hinch, S., 2004. Social versus genetic measures of reproductive success in sockeye salmon, Oncorhynchus nerka. Evol. Ecol. Res 6, 1167-1181.

Melotti, P., Roncarati, A., Garella, E., Carnevali, O., Mosconi, G., \& Polzonetti-Magni, A.,1992. Effect of handling and capture stress on plasma and androgen levels in brown trout, Salmo trutta morpho fario. Journal of Applied ichthyology, 8, 234-39.

Milla, S., Wang, N., Mandiki, S.N.M., Kestemont, P., 2009. Corticosteroids: friends or foes of teleost fish reproduction? Comp. Biochem. Physiol. A Mol. Integr. Physiol. 153, 242-251.

Moseley, P. L. (1997). Heat shock proteins and heat adaptation of the whole organism. J. Appl.Physiol. 83, 14131417.

Munday PL, Dixson DL, Donelson JM, Jones GP, Pratchett MS, Devitsina GV., 2009. Oceanacidification impairs olfactory discrimination and homing ability of a marine fish. Proc Natl Acad Sci USA; 106(6): 1848-52.

Nilsson, J. 1992. Genetic variation in resistance of Arctic char to fungal infection. Journal of Aquatic Animal Health, 4, 126-8

Noga, E. J., (2010) Fish Disease: Diagnosis and Treatment. Ames, IA: Wiley.

Nomura, T., M. Yoshimizu and T. Kimura. 1992a. An epidemiological study of furunculosis in salmon propagation. In Proceedings of the Oji International Symposium of Salmonid Disease (edited by T. kimura). Hokkaido University Press, Sapporo. pp. 187-193.

Ojanguren A.F, Braña F., 2003. Thermal dependence of embryonic growth and development in brown trout. J. Fish 
Biol., 62: 580-590.

Olafsen, J. A.,2001. 'Interactions between fish larvae and bacteria in marine aquaculture.' Aquaculture 200(1-2): 223247.

Olla, B.L. \& Davis, M.W.,1992. Phototactic responses of unfed walleye Pollock, Theraga chalcogramma larvae: comparison with other measures of condition. Environmental Biology of fishes, 35, 105-8

Olla, B.L., M.W. Davis, C.H. Ryer \& S.M. Sogard. 1996. Behavioural determinants of distribution and survival in early stages of walleye pollock, Theragra chalcogramma: a synthesis of experimental studies. Fish. Oceanogr. 5 (Suppl. 1): 167-178.

Palmisano, A. N., Winton, J. R. and Dickhoff, W. W.,2000. Tissue-specific induction of Hsp90 mRNA and plasma cortisol response in chinook salmon following heat shock, seawater challenge, and handling challenge. Mar. Biotechnol. 2, 329-338.

Pankhurst, N.W., and Carragher, J.F. (1992). Oocyte maturation and changes in plasma steroid levels in snapper Pagrus (= Chrysophrys) auratus (Sparidae) following treatment with human chorionic gonadotropin. Aquaculture., 101, 337-47.

Peters, G., M. Faisal, T. Lang, and I. Ahmed. 1988. Stress caused by social interaction and its effect on susceptibility to Aeromonas hydrophila infection in rainbow trout Salmo gairdneri. Dis. aquat. Org. 4:83-89.

Pickering, A. D. 1981. Introduction: the concept of biological stress. Pages 1-9 in A. D. Pickering, editor. Stress and fish. Academic Press, New York.

Piper, R.G., McElwain, I.B., Orme, L.E., McCraren, J.P., Fowler, L.G., Leonard, J.R. (Eds.), 1982. Fish Hatchery Management. American Fisheries
Society, Bethesda, MD, USA, p. 517.

Plumb, R.A., 1994, Variations of the least horizontal stress magnitude in sedimentary rocks: 1st North American Rock Mechanics Symposium, North American Rock Mechanics Association

Portz, D. E., Woodley, C. M. and Cech, J. J., Jr.,2006. Stress-associated impacts of short-term holding on fishes. Rev. Fish Biol. Fish., 16, 125-170.

Randall, D. J., and S. F. Perry. 1992. Catecholamines. In W. S. Hoar and D. J. Randall (eds.), Fish physiology, Vol. 12B, pp. 255-300. Academic Press, New York.

Reid, S. G., M. M. Vijayan, and S. F. Perry. 1996. Modulation of catecholamine storage and release by the pituitary-interrenal axis in the rainbow trout (Oncorhynchus mykiss). J. Comp. Physiol, 165B 665-676.

Reynolds, W.W., Covert, J.B. \& Casterlin, M.E., 1978. Febrile responses of goldfish Carassius auratus L. to Aeromonas hydrophila and to Escherichia coli endotoxin. Journal of Fish diseases, 1, 217-73

Romero, L. M. and Reed, J. M.,2005. Collecting baseline corticosterone samples in the field: isunder $3 \mathrm{~min}$ good enough?. Comp. Biochem. Physiol. A 140, 73-79.

Sadoul, B. and Vijayan, M. M.,2016. Stress and Growth. In Fish Physiology Biology of Stress in Fish, Vol. 35 (eds. C. B. Schreck, L. Tort, A. P. Farrell and C. J. Brauner), San Diego, CA: Academic Press.

Saeij, J.P., Vries, B.J, Wiegertjes, G.F., 2003. The immune response of carp to Trypanoplasma borreli: kinetics of immune gene expression and polyclonal lymphocyte activation. Dev Comp Immunol., 27: 859-874

Schreck, C. B., 2010. Stress and fish reproduction: the roles of allostasis and 
hormesis. Gen. Comp. Endocrinol. 165, 549-556.

Schreck,C.B., Solazzi, M.F., Nickelson T.E., and Johnson, S.T.,1989. Transportation stress affects performance of coho salmon, Oncorhynchus kisutch. Aquaculture, $82: 15-20$.

Selye, H., 1984. The stress of life. McGraw Hill Publ. 515 pp.

Selye,H., 1973.The evolution of the stress concept. American Scientist, 61, 629-99.

Short, C.E., Crim. L.W. and Morgan,M.J.1995. The effects of stress on spawning performance and larval development in Atlantic cod, Gadus marhua..In Reproductive Physiology of fish 1995.Goetz, F.W. and Thomas, P. in press. University of Texas, Austin.

Smart, G.R., 1981. Aspects of water quality producing stress in intensive fish culture. In: Pickering, A.D. (Ed.), Stress in Fish. Academic Press, London, pp. 277-293.

Soares, F., M.T. Davis and P. PousaeFerreira. 1994. Development of the swimb!adder of cultured Spanrs aurata L.: a histological study. Aquaculture Fish. Manage. 25:849-854.

Sodeberg, R.W. and Meade, J.W., 1987. Effects of rearing density on growth, survival, and fin condition af Atlantic salmon. Progr. Fish-Cult. 49: 280-283.

Summerfelt, S. T.,2003. Ozonation and UV irradiation - an introduction and examples of current applications.' Aquacultural Engineering 28(1-2): 2136.

Summers, C.H., 2002. Social interaction over time, implications for stress responsiveness. Integr Comp Biol, 42, 591-599.

Tamazouzt. L., Béatrice, C., Pascal F.,2000. Tank wall colour and light level affect growth and survival of Eurasian perch larvae (Perca fluviatilis L.). Aquaculture 182.: 85-90.
Tomasso, J. R., K. B. Davis, and B. A. Simco. 1981b. Plasma corticosteroid dynamics in channel catfish (Ictalurus punctatus) exposed to ammonia and nitrite. Canadian Journal of Fisheries and Aquatic Sciences 38:1106-1112.

Tomasso, J. R., K. B. Davis, and N. C. Parker. 1981a. Plasma corticosteroid dynamics in channel catfish (Ictalurus punctatus) during and following oxygen depletion. Journal of Fish Biology 18:519-526.

Torres-Núñez, E., Cal, R. and Rotllant, J. (2014), Phenotypic plasticity during early ontogeny in cultured turbot (Scophthalmus maximus): changes in dorsal and anal fin ray counts by water temperature. J. Appl. Ichthyol., 30: 762-766.

Tort, L., Sunyer, J.O., Gómez, E. and Molinero, A. 1996. Crowding stress induced changes in serum haemolytic and agglutinating activity in the gilthead sea bream Sparus aurata. Vet. Immunol. Immunopath. 51: 179-188.

Trushenski, J. T., Bowker, J. D., Gause, B. R. and Mulligan, B. L. (2012). Chemical and electrical approaches to sedation of hybrid striped bass: induction, recovery, and physiological responses to sedation. Trans. Am. Fish. Soc. 141, 455-467.

Tsai, C.L, Hoh, K.H. Effect of indomethacin on survival of Aeromonas hydrophila infected tilapia, Oreoclaromis mossambicus. Zool. Stud. 1995;34:5961.

Tucker, C.S. (Ed.), 1985. Channel Catfish Culture. Elsevier, Amsterdam, p. 657.

Tucker, C.S., Robinson, E.H., 1990. Channel Catfish Farming Handbook. Van Nostrand Reinhold, New York, p. 454.

Vadstein O, Bergh O, Gatesoupe FJ, GalindoVillegas J, Mulero V, Picchietti S., 2013 Microbiology and immunology of fish larvae. Rev Aquacult.,5:S1-S25

Valavandis, A., Vlahogianni, T., Dassenakis, M. and Scoullos, M.,2006. Molecula 
biomarkers of oxidative stress in aquatic organisms in relation to toxic environmental pollutants. Ecotoxicol. Environ. Saf. 64, 178-189.

Varsamos, S., Flik, G., Pepin, J.F., Bonga, S.E., Breuil, G., 2006. Husbandry stress during early life stages affects the stress response and health status of juvenile sea bass Dicentrarchus labrax. Fish Shellfish Immunol. 20 (1), 83-96

Vazzana, M., Cammarata, M., Cooper, E.L., Parrinello, N., 2002. Confinement stress in sea bass (Dicentrarchus labrax) depresses peritoneal leukocyte cytotoxicity. Aquaculture 210, 231-243.

Vijayan, M.M. and Leatherland, J.F. 1988. Effect of stocking density on the growth and stress-response in brook charr, Salvelinus fontinalis. Aquaculture 75: 159-170.

Vijayan, M.M. and Leatherland, J.F. 1989. Cortisol- induced changes in plasma glucose, protein and thyroid hormone levels, and liver glycogen content of coho salmon (Onchorynchus kisutch Walbaum). Canadian journal of Zoology, 67, 2746-50.

Vijayan, M.M., Ballantyne, J.S. and Leatherland, J.F. 1990. High stocking density alters the energy metabolism of brook charr, Salvelinus fontinalis. Aquaculture 88: 371-381.

Wedemeyer, G. A., and Goodyear, C. P., 1984. Diseases caused by environmental stressors. In. Inne, 0. (ed.) Diseases of manne animals, Vol. IV, Part 1, Plsces. Biologische Anstalt Helgoland, Hamburg, p. 424- 434.

Wedemeyer, G.A. 1997. Effects of rearing conditions on the health and physiological quality of fish in intensive culture. In FishStress and Health in Aquaculture Pp. 35-71. Edited by G.K. wama, Pickering, A.D., Sumpter, J.P and Schreck, C.B. Cambridge University Press, Cambridge.

Wedemeyer, G.A., 1996. Physiology of Fish in Intensive Culture Systems. Chapman \& Hall, ITP, New York,p. 232.

Wedemeyer, G. A., and D. J. McLeay. 1981. Methods for determining the tolerance of fishes to environmental stressors. In A. D. Pickering (ed.), Stress and fish, pp. 247-275. Academic Press, New York.

Wedemeyer, G. A., B. A. Barton, and D. J. McLeay. 1990. Stress and acclimation. In C. B. Schreck and P. B. Moyle (eds.), Methods for fish biology, pp. 451-489. American Fisheries Society, Bethesda, Maryland.

Wheaton, F.W., 1977. Aquaculture Engineering. Wiley, New York, p. 708.

Willmer, P., Stone, G., Johnston, I., 2000: Temperature and its effects. In: Willmer P., Stone G., Johnston I. (eds), Environmental Physiology of Animals. Blackwell Science Ltd., USA, pp. 192 244.

Wiseman, S., Osachoff, H., Bassett, E., Malhotra, J., Bruno, J., VanAggelen, G., et al., (2007). Gene expression pattern in the liver during recovery from an acute stressor in rainbowtrout. Comp. Biochem. Physiol. D 2, 234-244.

Zayan, R. (1991). The specificity of social stress. Behav Processes, 25.,81-93

Zenteno-Savín, T., Saldierna, R., AhuejoteSandoval, M., 2006. Superoxide radical production in response to environmental hypoxia in cultured shrimp. Comp. Biochem. Physiol C142, 301-308.

\section{How to cite this article:}

Saima Rehman, Adnan Hussain Gora, Irshad Ahmad and Sheikh Irfan Rasool. 2017. Stress in Aquaculture Hatcheries: Source, Impact and Mitigation. Int.J.Curr.Microbiol.App.Sci. 6(10): 3030-3045. doi: https://doi.org/10.20546/ijcmas.2017.610.357 